Vol. 2 | No. 4 | 2021 | Hal. 311-319

\title{
DIGITALISASI KEUANGAN DENGAN PEMANFAATAN APLIKASI PEMBUKUAN SECARA ONLINE UNTUK MENINGKATKAN DAYA SAING UMKM BESEK
}

\author{
Khoiriyah Trianti, Chici Elvina Widyawati, Delfia Anggraeni, Hudratil Yaumil \\ Husniah \\ Fakultas Imu Administrasi, Universitas Islam Malang \\ *korespondensi email: khoiryaht@unisma.ac.id
}

\begin{abstract}
ABSTRAK
Saat ini era teknologi semakin berkembang. Perkembangan era teknologi berbasis IT dan Internet of Thinks menyebabkan pemanfaatan teknologi berbasis Android dapat diakses kapan pun dan dimanapun. Pemanfaatan aplikasi berbasis android digunakan oleh semua bidang, baik bidang pendidikan, pemasaran, dan keuangan. Pemanfaatan apliaksi pembukuan berbasis Android dapat digunakan sebagai pengelolaan pencatatan transaksi keuangan secara mudah dan aplikatif bagi pelaku usaha. Pelaku usaha di Desa Duwet Dusun Kedampul Kecamatan Tumpang Kabupaten Malang mempunyai potensi alam bambu yang melimpah serta sebagian penduduk Desa banyak yang mempunyai usaha kerajinan anyaman besek yang terbuat dari bambu. Kegiatan UMKM di desa tersebut banyak yang belum memanfaatkan aplikasi berbasis Android. Berdasarkan hal tersebut maka dipilihlah Dusun Kedampul Desa Duwet sebagai lokasi untuk melaksanakan Kandidat Sarjana Mengabdi (KSM). Pelaksanaan kegiatan Pengabdian kepada Masyarakat ini dilaksanakan pada bulan Agustus - September 2021 yaitu berupa kegiatan Pengenalan pengelolaan keuangan bagi pelaku usaha, pengenalan aplikasi pembukuan berbasis Android. Beberapa manfaat praktis yang diharapkan dari pelaksanaan KSM, yaitu: (1) mereka mendapatkan informasi yang jelas dan utuh mengenai manajemen keuangan bagi pelaku usaha (2) mengenali aplikasi pembukuan berbasis android (3) peserta mampu melaksanakan aplikasi pembukuan berbasis android.
\end{abstract}

Kata Kunci: aplikasi pembukuan berbasis android; UMKM; Desa Duwet

\section{PENDAHULUAN}

Pelaku usaha mikro, kecil, dan menengah (UMKM) memiliki peran yang sangat penting dalam perekonomian di daerah. Kontribusi UMKM terhadap produk domestic regional bruto (PBRD) Jawa Timur bahkan mencapai 57,25\% (Prihatiningtias et al., 2021). Jumlah ini sangat signifikan dalam menopang pertumbuhan ekonomi. Pertumbuhan ekonomi di Jawa Timur mencapai 7,05\% dimana 59,78\% ditopang oleh pengeluaran atau konsumsi rumah tangga. Hal ini menjadi indikator bahwa UMKM di Jawa Timur memiliki ruang untuk dikembangkan dan diperluas pasarnya (Dinas Koperasi Usaha Kecil dan Menengah Provinsi Jawa Timur, 2017).

Dengan adanya pertumbuhan UMKM masih banyak UMKM yang belum mampu menyusun laporan keuangan (Ilsan et al., 2020). Dikutip dari tribunjogja.com, Keala Sub Direktorat Perbankan Syariah Badan Ekonomi Kreatif Yuke Sri Rahayu mengatakan meski belum terdata secara pasti UMKM yang telah memiliki kemmapuan untuk menyusun laporan 
keuangan, setiap mereka menggelar pelatihan terhadap UMKM, hanya 20\% yang mampu menyusunnya (Mahrizal, 2017).

Pelaku UMKM belum mengetahi pentingnya menyusun laporan keuangan atau melakukan pencatatan transaksi pada setiap aktivitas bisnis yang berkaitan dengan keuangan baik itu laporan laba rugi, laporan posisi keuangan, dan laporan perubahan modal (Ria, 2018). Alasan mereka tidak melakukan pencatatan keuangan atau pembukuan karena pembukuan itu dianggap hal yang sulit. Mereka menggangap bahwa aktivitas pencatatan hanya untuk perusahaan yang besar dan usahanya tetap berjalan lancar dan selalu mendapatkan keuntungan (Sedyastuti, 2018; Sudaryanto et al., 2012).

Pelaku usaha di Desa Duwet Dusun Kedampul Kecamatan Tumpang Kabupaten Malang sebagian penduduk Desa banyak yang mempunyai usaha kerajinan anyaman besek yang terbuat dari bambu. Para pelaku usaha di Kecamatan Tumpang masih menggunakan pencatatan secara manual bahkan ada yang tidak pernah melakukan pencatatan pemasukan maupu pengeluaran dari usaha yang dijalankan. Hal tersebut bisa menyebabkan perputaran arus keuangan yang tidak diketahui dan menimbulkan kerugian (Muljanto, 2020).

Berdasarkan latar belakang pemrmasalahan tersebut maka diperlukan media untuk mendukung pencatatan keuangan atau pembukuan kepada pelaku usaha khususnya anyaman besek di Desa Duwet Kecamatan Tumpang melalui aplikasi berbasis Android. Kegiatan pengabdian oleh peserta Kndidat Sarjan Mengabdi ini diharapkan memberikan wawasan dan pemahaman serta penerapan pencatatan keuangan secara mudah dan menggunakan smartphone.

\section{METODE}

Metode yang dilaksanakan dalam kegiatan ini adalah metode ceramah dan praktek. Metode pelaksaaan dilaksanakan secara bertahap yaitu:

1. Tahap 1: Analisis permasalahan usaha mitra

Pada tahap ini, dilakukan analisa permasalahan usaha mitra. Analisa dilakukan dengan cara wawancara secara langsung kepada mitra. Secara rinci permasalahan mitra di lokasi pengabdian kepada masyarakat dapat dijelaskan sebagai berikut: (1) Ketidaktahuan pelaku usaha untuk melakukan pencatatan keuangan bagi sebuah usaha, (2) Pencatatan keuangan dianggap hal yang sulit, (3) Pencatatan keuangan dilakukan secara manual dan mencatat pemasukan maupun pengeluaran saja, (4) Belum memahami bagaimana laporan keuangan baik itu laporan laba rugi, laporan perubahan modal, dan laporan neraca.

2. Tahap 2: Pengenalan Pembukuan Kepada Pelaku Usaha Anyaman Bambu

Kegiatan ini dilakukan oleh peserta Kandidat Sarjana Mengabdi pada saat melaksanakan program kerja pendampingan usaha anyaman.

3. Tahap 3: Pendampingan Dalam Pembukuan Kaeuangan Berbasis Android

Kegiatan ini dilaksanakan dengan cara sosialisasi kepada pelaku usaha di rumah salah satu perwakilan dari pelaku usaha. Kegiatan ini dihadiri oleh peserta Kandidat Sarjana Mengabdi dan 5 pelaku usaha. Kegiatan sosialisasi dilaksanakan menggunakan power point dan LCD Proyektor. Pengenalan pembukuan menghadirkan narasumber yang memahami pencatatan keuangan bagi pelaku usaha. Kegiatan ini dilaksanakan selama materi sebagai berikut: (1) 30 menit sesi 1 pengenalan teknologi informasi, (2) 40 menit sesi 2 Pencatatan Transaksi Keuangan bagi Pelaku Usaha dan Pembuatan Laporan Keuangan, (3) 100 menit sesi 3 Praktek Aplikasi Pembukuan Digital menggunakan Aplikasi Buku Kas, (4) 30 menit untuk evaluasi seluruh materi/kegiatan. 
Evaluasi dari kegiatan ini adalah melakukan tanya jawab secara langsung kepada peserta terkait dengan materi yang disampaikan. Output dari kegiatan ini adalah kemampuan dari peserta dalam menggunakan aplikasi pembukuan berbasis android.

\section{HASIL DAN PEMBAHASAN}

\section{Kegiatan Survey}

Kegiatan ini diawali dengan survey awal untuk analisa permasalahan mitra. Melakukan koordinasi dengan Ketua pengrajin dusun kedampul pada tanggal 19 Agustus 2021. Mengadakan pertemuan dengan pelaku usaha anyaman besek. Dalam pertemuan ini dilakukan diskusi tentang proses pengolahan bamboo yang diubah menjadi anyaman besek yang berkualitas dan mempunyai nilai jual yang tinggi. Sekaligus survey terhadap penggunaan pembukuan yang dilakukan oleh pelaku usaha.

\section{Kegiatan Persiapan Pelaksanaan Program Kemitraan Masyarakat}

Pada tahapan ini tim pengabdi melakukan koordinasi dengan pihak desa dan kelompok pengarajin anyaman bambu. Melakukan rekrutmen peserta, rekrutmen peserta dilakukan dengan menjalin komunikasi yang baik dengan kelompok pengrajin anyaman bambu. Rekrutmen peserta dilakukan dengan memperhatikan jenis kelamin, artinya proporsi yang dititikberatkan adalah kepada ibu rumah tangga yang memiliki banyak waktu luang. Namun, baik pria maupun wanita, asal memenuhi kriteria, dipandang mau dan mampu mengikuti pelatihan dan dipandang bersedia untuk menerapkan ilmu yang diperoleh pada pelatihan

\section{Kegiatan Pelaksanaan}

Kegiatan pendampingan terhadap pemanfaatan aplikas pembukuan keuangan berbasis android dilakukan selama seminggu 2 kali oleh mahasiswa Kandidar Sarja Mengabdi. Waktu yang agak senggang itu kami terapkan dengan maksud memberikan kesempatan kepada peserta pelatihan untuk menerapkan ilmu yang diperoleh di rumah masing-masing. Karena peserta pelatihan sebagain besar telah diberikan keterampilan yang berguna untuk dirinya masing-masing.

Pelaksanaan kegiatan inti yaitu berupa pelatihan dari narasumber dilaksanakan pada tanggal 19 Agustus 2020, kegiatan ini diikuti oleh peserta dengan sangat antusias. Dalam pelaksanaannya masing-masing peserta menggunakan 1 unit handphone dan membawa kertas atau buku beserta pensil sebagai alat untuk mencatat materi. Manfaat dari kegiatan ini adalah peserta mendapatkan informasi baru tentang aplikasi buku kas dan langsung mengaplikasikannya.

Kegiatan ini dilakukan dalam 3 sesi yaitu: pengenalan teknologi informasi, pembukuan keuangan berbasis digital, praktek pembukuan keuangan digital, dan evaluasi yang dilakukan menggunakan tanya jawab.

a. Sesi 1 Manajemen Keauangan Digital

Pada sesi ini peserta diberikan materi tentang pembukuan keuangan digital, mulai dari pengantar, jenis-jenis laporan keuangan, pentingnya melakukan pencatatan keuangan/transaksi, manfaat apabila peserta menggunakan pembukuan keuangan digital.

b. Sesi 2 Praktek Aplikasi keuangan digital

Pada sesi ini peserta disuruh menginstall aplikasi buku kas di playstore. Setelah peserta install aplikasi buku kas, peserta dibimbing untuk register terlebih dahulu. Aplikasi Buku Kas sendiri memiliki beberapa fitur antara lain: menu transaski, menu utang piutang, penjualan, menu stok barang, pembukuan, laporan keuangan. Kegiatan ini dilakukan selama sesi berlangsung. Untuk memahami lebih dalam dan 
penerapannya dilakukan pendampingan secara berkala seminggu 2 kali oleh mahasiswa Kandidat Sarjana Mengabdi.

c. Sesi 3 Evaluasi

Pada sesi ini dilakukan dengan melakukan penilaian terhadap kegiatan yang dilaksanakan. Penilaian dilaksanakan dengan tanya jawab kepada peserta. Peserta mengikuti kegiatan dengan sangat antusias. Kaegiatan ini diharapkan akan memberikan dampak positif khususnya meningkatkan kemampuan pembukuan digital dengan aplikasi buku kas. Tampilan aplikasi buku kas adalah sebagai berikut:

- Tampilan aplikasi bukukas, mulai tahap instalasi sampai tahap mendaftar.

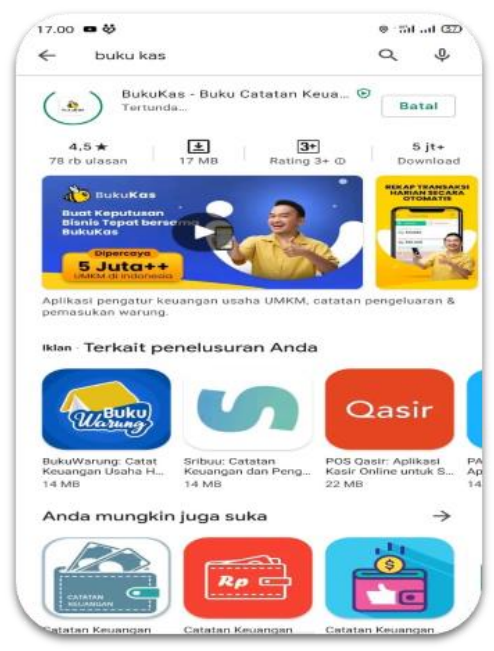

Gambar 1. Download dan instal aplikasi BukuKas di google playstore atau app store.

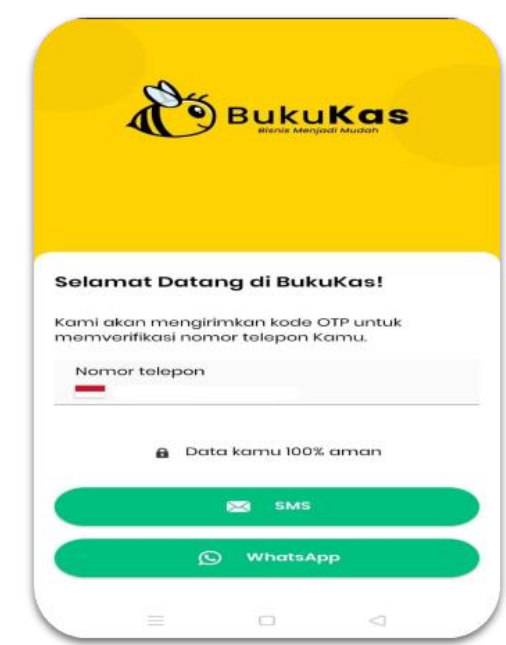

Gambar 2. Buka aplikasi tersebut dan isikan nomer telepon lalu pilih cara untuk mendapatkan kode OTP. 


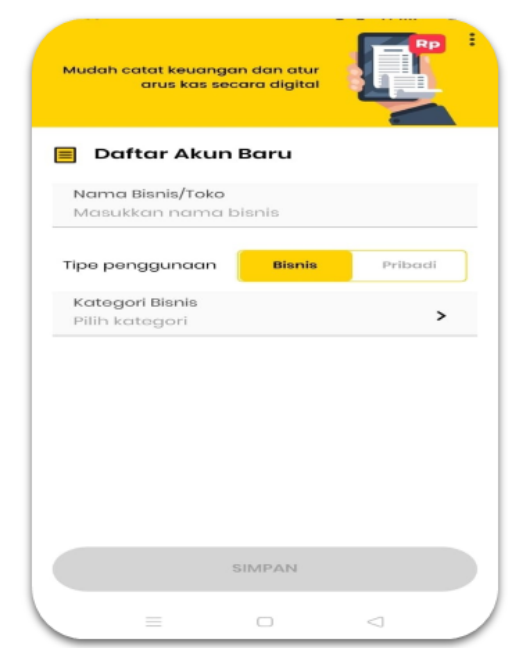

Gambar 3. Masukkan nama bisnis atau toko kemudian pilih tipe penggunaan dan kategori bisnis setelah itu klik simpan.

- Transaksi utang piutang

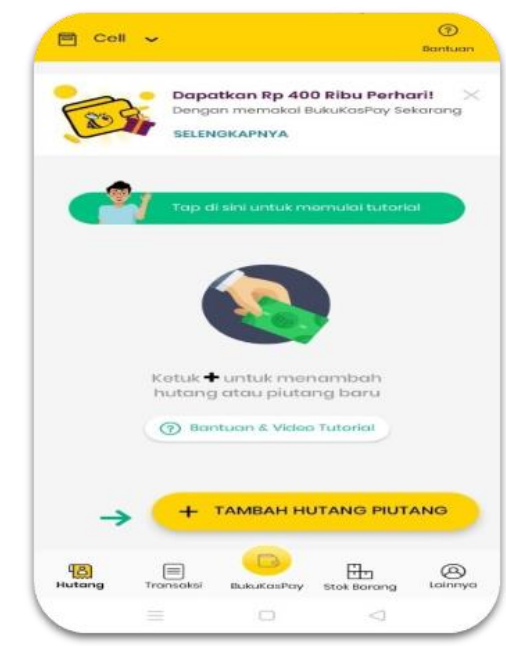

Gambar 4. Pilih menu hutang lalu pilih + Tambah Hutang Piutang

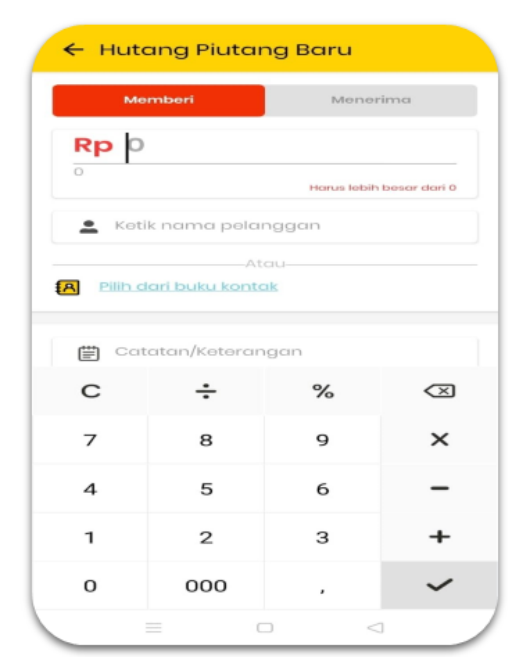

Gambar 5. Pilih kategori Memberi dan tentukan jumlah hutang, nama pelanggan dan detail hutang. (Jika ingin memberikan hutang). 
Trianti et al.

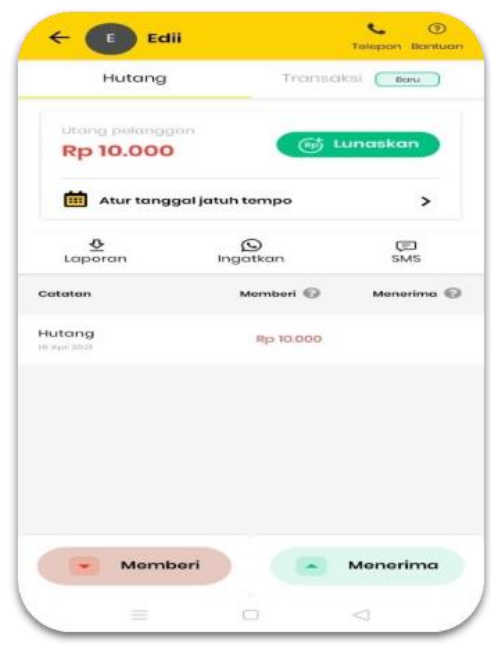

Gambar 6. Pada menu transaksi bisa mengatur tanggal jatuh tempo dan bisa mengingatkan pelanggan melalui sms atau whatsapp.

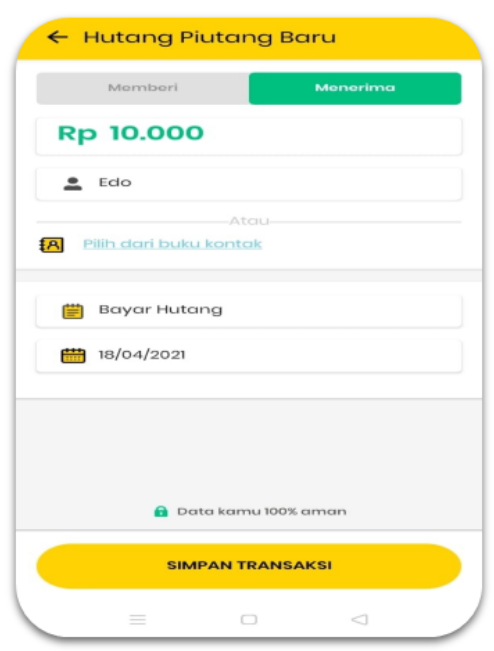

Gambar 7. Jika ingin melakukan hutang pilih kategori Menerima lalu pilih nama, catatan, serta tanggal kemudian pilih simpan transaksi.

- Mengatur tambah Transaksi dan melihat grafik

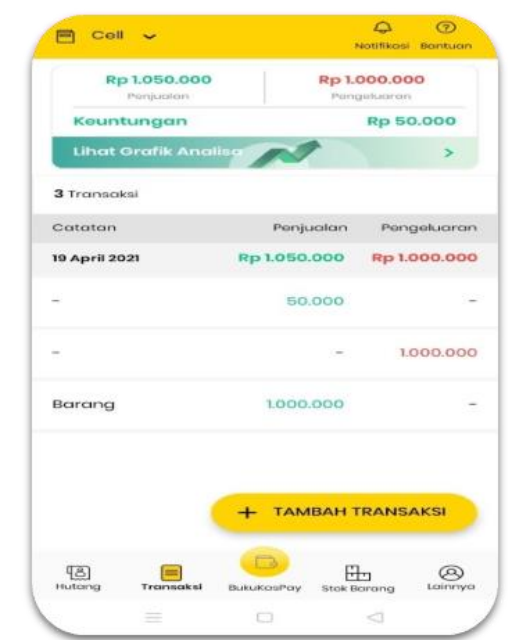

Gambar 8. Pilih menu transaksi lalu pilih + Tambah Transaksi. 


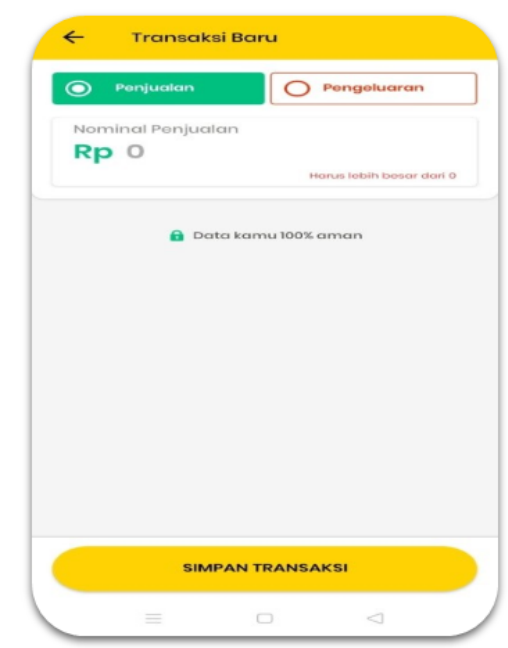

Gambar 9. Jika transaksi penjualan, pilih Kategori penjualan dan pilih nominal. (Jika kategori pengeluaran pilih nominal Kemudian pilih simpan transaksi)

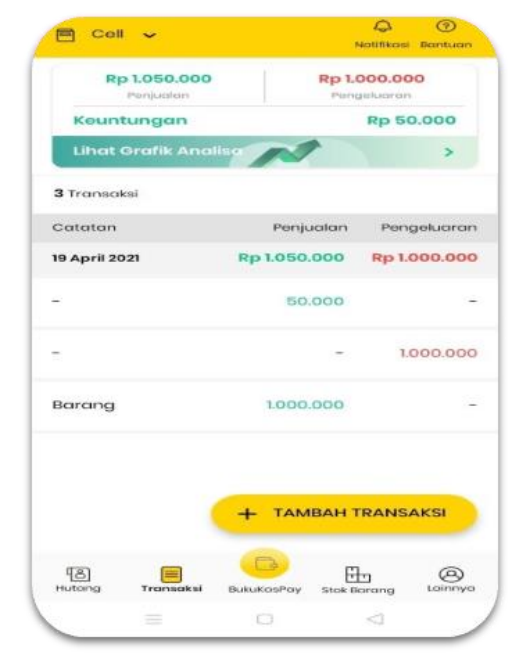

Gambar 10. Pada menu utama transaksi dapat dilihat Keseluruhan transaksi besarnya penjualan dan pengeluaran serta keuntungan yang didapat.

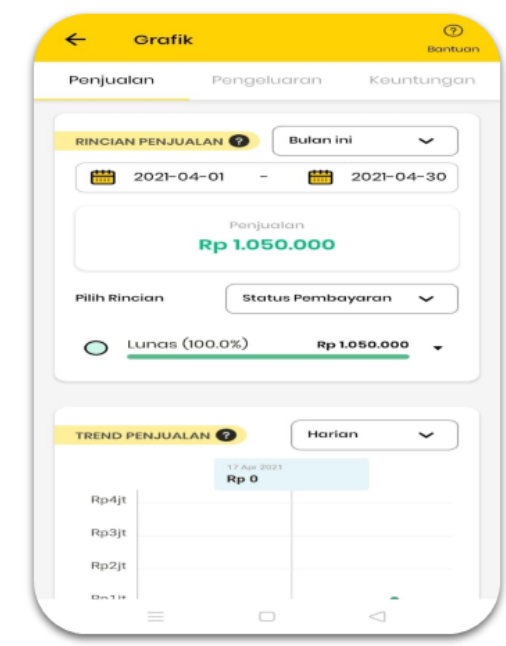

Gambar 11. Untuk melihat grafik transaksi pilih lihat grafik analisa lalu bisa Memilih kategori antara penjualan, Pengeluaran dan keuntungan. 
Trianti et al.

- Mengatur stok barang

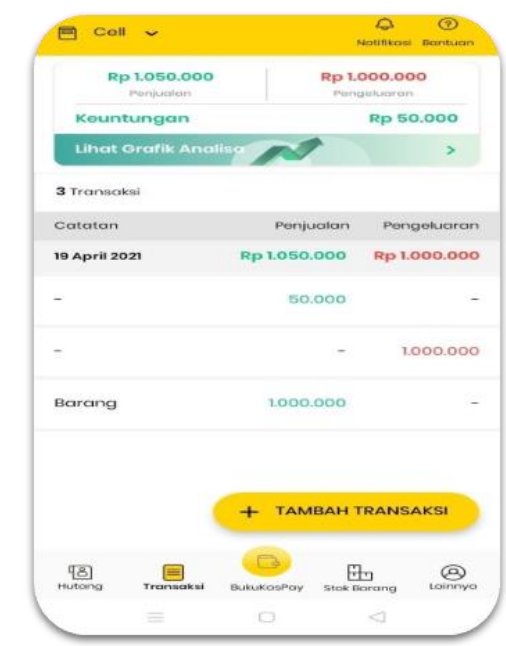

Gambar 12. Pada menu stok barang lalu pilih + Tambah Barang

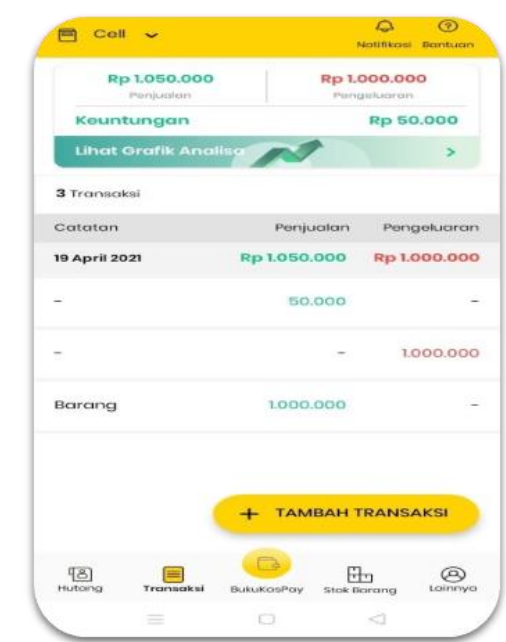

Gambar 13. Ketik nama barang yang ingin dimasukan kemudian pilih jumlah Barang yang tersedia dan stok minimum.

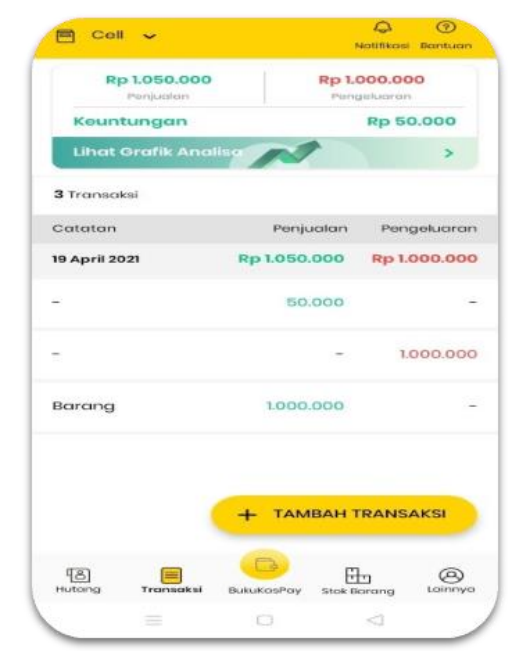

Gambar 14. Stok barang bekerja secara otomatis 
Stok barang ini bekerja secara otomatis, jika terjadi transaksi atas barang tersebut maka sistem akan mengurangi stok jumlah barang. Jika stok jumlah barang sudah mencapai batas minimum maka barang akan dialihkan ke kategori stok menipis untuk mengingatkan bahwa stok barang tinggal sedikit.

\section{KESIMPULAN}

Hasil yang didapatkan dari pengabdian kepada masyarakat ini cukup baik, yakni: Pemahaman pelaku usaha terhadap penggunaan aplikasi pembukuan digital. Peningkatan kemampuan bagi pelaku usaha untuk melakukan pembukuan. Hal ini akan bermanfaat bagi keberlangsungan usaha dan meningkatkan daya saing. Kegiatan pembukuan dilakukan agar pelaku usaha memahami arus keuangan.

\section{UCAPAN TERIMA KASIH}

Ucapan terima kasih disampaikan kepada Universitas Islam Malang yang telah memberikan kesempatan kepada kami untuk melaksanakan kegiatan pengabdian kepada masyarakat, Desa Duwet yang memberikan izin kami untuk melaksanakan pengabdian kepada masyarakat, masyarakat Desa Duwet yang selalu mendukung dan turut membantu dalam segala kegiatan yang telah kami langsungkan, teman-teman yang turut berpartisipasi dalam kelancaran seluruh kegiatan pengabdian.

\section{DAFTAR RUJUKAN}

Dinas Koperasi Usaha Kecil dan Menengah Provinsi Jawa Timur. (2017). Rencana Kerja Tahun 2018.

Ilsan, M., Salim, M., \& Husain, T. K. (2020). Pelatihan teknik menyusun laporan keuangan untuk umkm agribisnis. Jurnal Inovasi Hasil Pengabdian Masyarakat (JIPEMAS), 3(2), 102-110. https://doi.org/10.33474/jipemas.v3i2.5993

Mahrizal, V. (2017). 80\% UMKM Belum Mampu Susun Laporan Keuangan. TribunJogja.Com. https://jogja.tribunnews.com/2017/10/25/80-umkm-belum-mampu-susunlaporan-keuangan

Muljanto, M. A. (2020). Pencatatan dan Pembukuan Via Aplikasi Akuntansi UMKM di Sidoarjo. Jurnal Ilmiah Pangabdhi, 6(1), 40-43. https://doi.org/10.21107/pangabdhi.v6i1.6926

Prihatiningtias, Y. W., Prabandari, S. P., Cahaya, D. N., Kusumadewi, A. W., Anggraeni, O. L., Nisa, K., Rizkiyah, A., \& Arasy, F. H. (2021). Peningkatan pengetahuan aspek perpajakan dan kualitas pengelolaan produk pada kelompok UMKM. Jurnal Inovasi Hasil Pengabdian Masyarakat (JIPEMAS), 4(1), 78-89. https://doi.org/10.33474/jipemas.v4i1.8674

Ria, A. (2018). Analisis Penerapan Aplikasi Keuangan Berbasis Android pada Laporan Keuangan UMKM Mekarsari, Depok. Sosio E-Kons, 10(3), 207-219. https://doi.org/10.30998/sosioekons.v10i3.2844

Sedyastuti, K. (2018). Analisis Pemberdayaan UMKM Dan Peningkatan Daya Saing Dalam Kancah Pasar Global. INOBIS: Jurnal Inovasi Bisnis Dan Manajemen Indonesia, 2(1), 117-127. https://doi.org/10.31842/jurnal-inobis.v2i1.65

Sudaryanto, Ragimun, \& Wijayanti, R. R. (2012). Strategi Pemberdayaan UMKM Menghadapi Pasar Bebas Asean. In https://www.kemenkeu.go.id/sites/default/files/strategi pemberdayaan umkm.pdf 